\title{
The Analysis of Summative Assessment and Formative Assessment and Their Roles in College English Assessment System
}

\author{
Wenjie Qu \\ English Department, Capital University of Economics and Business, Beijing, China \\ Chunling Zhang \\ English Department, Capital University of Economics and Business, Beijing, China
}

\begin{abstract}
Taking English teaching summative assessment and formative assessment system as the entry point, the essay illustrates the effect of the assessments on College English teaching and its great influence on English learning by combing it with practical teaching experience deeply and broadly. It also points out that students' real English level can not only rely on a single evaluation mode. Summative assessment and formative assessment have different form and different function. They should be combined together during the teaching and learning process. Then the students' English level will be effectively evaluated, and it will better guide the foreign language teaching.
\end{abstract}

Index Terms —English teaching, summative assessment, formative assessment, outcome

\section{INTRODUCTION}

Assessment is a broad term defined as a process for obtaining information that is used for making decisions about students; curricula, programs, and-schools; and educational policy (American Federation of Teachers, National Council on Measurement in Education, and national Education Association, 1990). Decisions about curricula, programs, and schools include decisions about their effectiveness (summative assessment) and about ways to improve them ( formative assessment) (Anthony J \& Susan,2005). When we want to know students English level, we usually formally collect information through students' paper-and-pencil tests within a given time, or informally record information of students' performance on oral participation, homework, presentation. Assessment is a very important activity during foreign language teaching. It's a scientific method of the evaluation of teaching quality and learning outcome. Efficient evaluation is like a mirror. Because it timely feeds back the information of teaching and learning, makes teachers and students see the achievements and shortcomings clearly and improve teaching and learning efficiently. Whatever assessment is taken, we should be clear about learning targets and what assessments should be taken during the process of teaching and learning.

\section{LEARNING TARGETS AND ASSESSMENTS}

Teaching is the process that teachers use instructions to help students achieve their learning targets. Nitko (et al., 2005) pointed out some learning targets are cognitive, meaning that they deal with intellectual knowledge and thinking skills; other learning outcomes are affective, meaning that they deal with how students should feel or what they should value. Of course, this theory are consistent with our student learning objectives. Besides, from Allen also (et al., 1997) pointed out the assessment has four targets: to carry out teaching research, to understand students' learning progress, to guide teaching and reflect the ultimate teaching and learning case. For the learning targets, there're general learning target goal and specific learning target. General learning target goal is a statement of an expected learning outcome deriving from educational goal. A specific learning target is a clear statement about what students are to achieve at the end of a unit. In China, the college English curriculum is the general learning target for all the universities which says College English teaching is that students have strong ability of reading and listening, speaking and writing, translation, they can communicate in English. College English teaching should help students lay a solid foundation of the language to master a language study method, to meet the needs of high social development and economic development.while the specific learning target is more detailed. For example, in the unit of "Work roles", students are to achieve to talk the subject of "work"; to write "report"; to grasp the general and specific information while listening to a material. Once we are clear about the learning objectives, we are also make sure what kind of evaluation method should be taken. But it is very important when teachers use assessments, they need consider the choice of the method of the evaluation which must meet the need of students, the outcomes that teachers assess are the process and strategies students use to solve real life problems, and they also should take into account of what kind of effect the assessments have on building students' confidence and making progress that different assessment will produce. Therefore, on one hand, the 
evaluation methods should be used to achieve the targets of assessment. On the other, it should consider the effect it has on students. As some types of assessments' influence on students are as light as a feather that students imperceptible to them, while others are more apparent, relatively have large impact. In fact, all forms of evaluation for teaching are very important, because the effective evaluation has the following effects: It makes the teachers know the teaching effect. It helps teachers understand the whole class, decide whether to continue the current work mode or take another way. It helps teachers find that individual students may have special problems. It helps teachers understand the class and each student's progress. It provides efficient feedback to the teacher the students' the basic information, and as a basis for recognition and awards. It helps teachers evaluate their performance and teaching program, and make proper adjustment. (Janet, 2002)

In the classroom, teachers need to make particular decisions to adapt to the different needs of students, which is very important to determine the teaching scheme. At present, in China, universities usually adopt summative assessment and formative assessment to evaluate students' learning which has the significance for teaching and learning.

\section{Summative Assessment AND Its Role in Foreign LANGuAGe Teaching}

Summative assessment is to evaluate student learning and teachers teaching after a teaching period (Anthony $\mathrm{J} \&$ Susan M, 2005). It has a clear evaluation criteria. American educator Bloom (et al.,1971) pointed out that summative assessment is an assessment of the course, the education program's validity and education research in order to classification, identification, evaluation of progress after a teaching program or the end of the term. Summative assessment is that teacher wants to find out what the students can remember about the course material so that a mark cab be determined. It lets the teacher sum up" what the students have learned, or to make judgment (Luo Shaoqian, 2003).

Nowadays in China, the universities' summative assessment is undertaken according to the provisions of the nation's syllabus. It is a curriculum standard test which is a conventional criteria to measure students' English level. For example, the national Band 4 and Band 6 English Tests for non - English Major students and English final examinations at the end of the term. These examinations are summative assessment, also called the achievement test which is made basing on the outline of what is taught and what to be tested. It evaluates and measures what students grasp in the learning situation after a learning period. For example, multiple-choice test is one of the typical summative assessment. Multiple-choice test belongs is formal and objective. It can be a direct assessment of certain abilities (Anthony $\mathrm{J} \&$ Susan M, 2005).It usually has several items which is used in teaching, election, or in other fields. In our university final examinations, we use multiple choice test such as listening, vocabulary and structure, cloze and reading comprehension for the purpose of grading students learning results. There are advantages of multiple choice test. Firstly, it is a very efficient way of testing. In a given time, a great variety of learning target is assessed. There are $70 \%$ part of exam is multiple choice test in our examination. Secondly, the possibility of bias that teachers grade scores for students is minimized in the final score. The result is more reliable and validity, because teachers can't put their subjective opinion on the answers. Thirdly, multiple choice test make teachers more easily find students' common problem. For example, in a 20 items multiple -choice test, if most students choose "A" which is a wrong answer, then teachers know that most students choose the wrong answer. Lastly, it lows the cost and saves time. Because machine grades the score, it is faster than man's hand work. Its result can be fed back to teachers quickly so that teachers know what the outcome is. Teachers can compare the present students' grades with that of the past so as to decide whether to continue the current mode of operation or take another way. This assessment helps teachers make proper teaching adjustment and improve teaching program timely. Linguist Heaton (1989) argued that summative assessment which takes the main role objective tests treats language as a separate component and has very high reliability. As summative assessment provides very accurate quantitative data for teaching analysis, teachers can analyze the test results to guide the next teaching instruction .For example, accordance with the collected data of this year's final examination, we find the average grade of vocabulary is lowest in the test. So we decide to strengthen students' learning of vocabulary in the next term. Out of question, the information that summative assessment provides can guide teachers timely discovers teaching problems and adjusts the teaching content and teaching methods. In the mean time, it can help students find their problems in study, and adjust their learning objectives and learning methods. But everything has two sides. There're disadvantages of summative assessment. Firstly, students can guess the answer when they have no time or when they had no idea to make the choice. So some students may be lucky in the exam. Secondly, students must choose one answer form the choices which restrains students' subjective opinion of writing the answer, even if they have the idea of how to write out answer. An example of finding similar meaning word: "This student was excelled from school because he had forged some document for overseas study. A. Frustrated B. formulated C. fabricated D. facilitated". The answer is "C". The students may not know the word of "fabricated", but he knows the word of "forge". He is able to write out the right answer instead of making false document. But he has no chance to do it. It can be seen that multiple choice test restrains his high skill of thinking such as creation and critical thinking. Thirdly, less knowledgeable students may guess answers. They may be lucky in such test. Lastly, too much use of multiple choice tests may mislead education into undesirable ways. For example, teachers and students may be pushed to put a lot of energy to study some "skills" to make a "right" answer, not on the exploring knowledge. Students' ability creation is ignored. Actually, in our teaching, we find that some students who scored high have poor ability of speaking English and less participation in classroom 
discussion, and some with good speaking ability have low marks on paper-and-pencil test. Obviously the summative assessment can't show students' real English level. Though it makes teachers able to get quick overall results but not complete. It is lack of comprehensive evaluation to the students' ability of using English, especially the ability of speaking English in a communicative situation (Luo Shaoqian, 2003). Obviously this way of single assessment cannot reflect the level of learning. If most or all of the items in our test tests students simple recall, a short answer test is preferred (Anthony J \& Susan M, 2005). Thus in our university examination, the amount of multiple choice should be reduced. Short answer test should take the place of part of multiple choice, because short answer can provide students' large space of thinking and make them build up their own opinion. The students in our university has relatively high level of English. They has the ability of analysis, synthesis and evaluation. Most of all, formative assessment makes up for the irrationality and regret caused by summative assessment, for it emphasizes to cultivate students' motivation, creation and critical thinking during the process of assessment.

\section{Formative Assessment AND Its Role in FoREIGN LANGUAGE LEACHING}

Formative assessment is the investigation, evaluation and analysis of record of daily students' learning activities. It is the use of systemic evaluation in curriculum development, teaching and learning so that these three process are improved in any one process (Bloom, et al., 1971). Formative evaluation is different from the summative evaluation. Its main purpose is to help teachers to guide students' learning Its criteria usually is not so clear, and does not have to pass the test to complete assessments (Anthony J \& Susan M, 2005). Formative assessment can often be performed, whether formal or informal. It provides for the teacher with more detailed, a continuous feedback, and a comprehensive understanding of what help students need so that teachers can decide to use what kind of teaching methods according to the different students' need. Bloom (et al., 1971) pointed out that formative assessment must not have any association of evaluating grades so that learners will not fear, but rather look at it as a learning aid. There's a wide range of sources of information for formative evaluation. British linguist Widdowson (1990) emphasized on cultivating students' ability of using language. He pointed out that language ability is actually the process capability, namely, language ability is the process of transmitting information, inducing, reasoning and problem solving. Some linguists also pointed out, from the social function of language, language is the process of doing, instead of knowing.

Formative assessment also is consistent with ancient Chinese teaching perspective and the theory of the nature of language---teach students in accordance with their aptitude. The famous Song dynasty Neo-Confucianism Zhu Xi pointed out that Confucius taught according to each students' aptitude (Wang Hongliang, 2005). Educator Confucius taught students in accordance with their aptitude in the teaching practice as early as two thousand years ago. To teach students in accordance with their aptitude is to have a comprehensive understanding of students. In the teaching, Confucius tried to understand the very thoroughly every of his students moral, intelligence, personality, interests. Under this premise, Confucius used different methods for teaching in order to obtain the best effect. So, it is necessary to take formative evaluation when evaluating students' performance in the classroom. For instance, in our university, our students have different backgrounds. Some once were English teacher, some did interpreting work, some were foreigners, some worked in foreign companies and English was their daily working language. The difference determines their ability and English level. Some students got high score in summative assessment but with less ability of spoken English, some didn't score high but with good ability of using English in a real communication situation. Thus only to take a unified summative assessment on the evaluation of our students would be unfair and unjust, and would not favor students to improve their real standard of English. Therefore, in our teaching activities, we adopted several styles of formative assessment with the purpose of providing students' a wide space for reaction, motivation and critical thinking.

A. Drama Performance. Performance can evaluate students' performance in national curriculum

in. Because the show emphasizes the ability of investigation and research, performance and literature have very close combination (Wu Shiying, 1999). Drama performance can gave our students full chances of playing their talents and abilities such as the ability of using language, imitation, organization and coordination and so on. In the classroom students played drama in groups. They wrote content, plot and direct by themselves. In this process students gave full play of their competence and capacity. They learned to exchange and cooperation, to integrate what they had learnt in different areas of as a whole, to help each other and so on. It made teachers knew more about the impact of emotional factors on learning.

B. Interviewing with Students. Interviewing with students helps teacher to diagnose what difficulties students have during their learning and give them suggestions for further learning. Diagnostic assessment of learning difficulties has two related purposes: (a) identifying which learning targets a students has not mastered and (b) suggesting possible causes or reasons why a student has not mastered the learning targets (Anthony J \& Susan M, 2005). In our teaching, teachers were required to have an interview with individual student regularly. Students explain their thinking and or answer question, teachers follow students' response to gather informal diagnostic information. For example, after the drama performance, teachers asked students to give their opinions of the activity frankly. Usually teachers began with general questions and then specific questions such as

1) "Do you like this drama?"

2) "How well do your group accomplish your performance?"

3) "How many marks are you going to grade for your performance?" 
4) "What is your group members advantage and disadvantages when you designed your play?"

5) "How did you go about when plying this drama?"

6.) "What problems did you encounter?"

7) "Did you solve the problem now?"

8) "What are your goals for your next piece?"

During the interview, teachers took down students' thinking, the problems they were faced with, the reasons of the problems and recommendations to solve the problems for students. The teachers should note that the interview should be taken in a friendly and kind atmosphere.Teachers should not threat students.

C. Feedback .Feedback in the assessment is very important. Its purpose is to encourage and help students to learn better. There are many ways of feedback like written assignments, oral homework, quiz, performance and so on. Feedback can be both assignment reviews, modification, symbols, annotations, interview with the individual or give comments to all the students. During the classroom activities, teachers carefully observed and record every student's performance. After activities teachers immediately gave feedback to students, such as pointing out students' strengths and deficiencies in the performance and gave them instructions of how to do it well next time. Teacher also had individual dialogue with students in order to better understand the students. No matter what formative assessment is undertaken, teachers' feedback must be objective and fair, because if formative assessment doesn't dealt well, it will not produce good results. For example, in order to encourage the students, no matter how students perform, some teachers always say to students "very good", or "good". If students find no matter how they perform, they will easily get praise. This will be very hard to move students to a higher goal. Therefore, although praise is very important, it must be based on students' true progress. Students need to know where they do well, so that they can progress faster. Feedback also helps students have self-assessment.Richard G. Sober (2009) stressed self and peer assessment can make students reflect on their own contribution to the team and also voice their opinions on their co-workers and it is essential they have confidence that a sense of fairness will prevail in the marking process.

Formative assessment is not perfect, it has advantages. For instance, other's opinions are not objective, often based on incomplete information; some students cannot express themselves well in front of other students, inefficient students' conversation may be irrelevant to assessing their achievement; some learning targets cannot be assessed by short oral responses; they require longer time frames in which students are free to talk, create and respond (Anthony J \& Susan M, 2005). Though formative has the above disadvantages, we may take measure to avoid them. Keep the conversation on a professional level; be careful not to misunderstand students attitude; kindly ask questions and patiently wait for students' response; treat every student equally----don't ignore and punish students who make mistakes or praise a lot of students who participate more often. Though formative assessment doesn't have standard criteria, as long as teachers reasonably deal with it, it will serve the teaching and learning well. After all, Formative assessment helps teacher and students find out the students' achievements in the performance that summative assessment doesn't. At the same time, it also finds out students' specific problems existed. This assessment not only allows students to better play their strengths, but also provides specific help for individual student. Formative assessment can not only praise and encourage students, but also help students who are lack of confidence realize their own progress and help everyone establish histher direction and goals. There's no doubt that it evaluates a student's English level and the ability of using English comprehensively and objectively and effectively and timely guide teaching. High quality formative assessment and feedback can improve the quality of learning ( Black \& Wiliam, 1998).

\section{CONCLUSION}

Summative assessment and formative assessment have different forms and functions. The types of the choice of assessments depends on what we want to know, what the purpose is. To assess effectively, the type must match the results required, but this is not to say that there is only one option, instead there are usually several different options. We choose the type based on the available resources, and use the most familiar and most effective way to assess. The national or the university's unified summative assessment is very authoritative. Summative assessment focus more on the objective test and more easily to get students overall English level, In the present situation, summative assessment is still necessary. Because in most universities, the ratio of teachers and students usually is 1:100.So at the fixed locations, within a given time paper-and-pencil test is one of the most effective method of evaluation of learning and teaching. in China. But it is undeniable that summative assessment is hard to test students' ability of using English especially speaking ability in a real communicative set to a certain extent. Moreover, summative assessment is also very difficult to make teachers have in-depth understanding of individual differences of each student, thus there is imperfection for summative assessment to evaluate students' English level. However formative assessment directs more on students' individual performance. It has important significance for the inspection of each student progress and achieves the desired teaching standards. It is helpful for teachers to diagnose and find individual differences in performance, to reflect, to foster students' critical thinking. Yet, if we use one type of assessment method for a long period, it's possible to cause negative effects. Therefore formative evaluation and summative evaluation can not be completely separated. In a certain range, effective evaluation can make teacher use different ways of evaluation so they will have a comprehensive understanding students' ability. Therefore, we should put summative assessment and formative 
assessment to combine together in order to guide teaching and get more comprehensive and reasonable assessment of student learning, make students play a variety of potential as much as possible.

\section{REFERENCES}

[1] Anthony J.NitkolSusan M.Brookhart.(2005). Education Assessment of Students. New Jersey: Person Education Ltd.

[2] Black,P., \& Wiliam, D. (1998).Assessment and Classroom Learning. Assessment in Education 5,7-74.

[3] Bloom, B. S., Hastings, J.T., \& Madaus, G. F. (1971). Handbook on formative and summative evaluation of student learning. New York: MacGraw-Hill.

[4] J.P.B. Allen, S.P. Corder, Alan Davis. (1997). Edinburgh Course in Applied Linguistics: Testing and Experimental Methods. Oxford: Oxford University Press

[5] H.G. Widdowson. (1990). Aspects of language Teaching. Oxford: Oxford University Press.

[6] J.B. Heaton. (1989). Test in Contest. London: Longman

[7] Janet Kay. (2002). Teaching Assistant's Handbook. London and New York: MPG Books Ltd, Bodmin.

[8] Richard G. Sober. (2009). Team working and Peer Assessment: The assessment process as an aid to effective learning in creative group project work. The Higher Education Academy http://www.adm.heacademy.ac.uk/resources/case-studies/teamworking-and-peer-assessment-the-assessment- (accessed 20\2\2010)

[9] Luo Shaoqian. (2003). The Research of English Classroom Teaching. Beijing: Foreign Language Teaching and Research Press.

[10] Wang Hongliang. (2005). The History of Ancient Chinese Education. Beijing: Xingqiu Publishing House.

[11] Wu Shiying. (1999).The History of Foreign Education History. Beijing: People's Education Press.

[12] American Federation of Teachers, National Council on Measurement in Education, \& national Education Association. (1990). Standard for teacher comprehension in educational assessment of Students. Http://www.unl.edulburoslbimmlhtml (Accessed 13\12\2011)

[13] http://jwc.nxu.edu.cn/menu/kcjs/yscl1/dxyy2.htm (accessed 20\12\2011)

Wenjie Qu, born in April, 1963, graduated from Flinders University as master of pedagogy in Australia in 2010.Now she is teaching English as an associate professor of English Department of Capital university of Economics and Business, Beijing, China .Her research field is applied linguistics and pedagogy. She has published many articles.

Chunling Zhang, born in March, 1964, graduated from Flinders University as master of pedagogy in Australia in 2007. Now she is teaching English as an associate professor of English Department of Capital university of Economics and Business, Beijing, China .Her interest is business English and pedagogy. She has published many articles. 